\title{
SURFACE MINE TO BIOMASS FARM: GROWING SHRUB WILLOW (SALIX SPP.) IN NORTHEASTERN WEST VIRGINIA - FIRST YEAR RESULTS ${ }^{1}$
}

\author{
Bart Caterino $^{2}$, Jamie Schuler, Shawn Grushecky, and Jeff Skousen
}

\begin{abstract}
Shrub willow (Salix spp.) has been a focus of international efforts to develop renewable alternatives for fossil fuels and to sequester carbon from earth's atmosphere. One area of interest has been to plant and cultivate willow on reclaimed mine lands. West Virginia's coalfields provide significant land area for incorporating willow cultivation into reclamation. The objective of this study was to develop silvicultural treatments to overcome the most common properties of mine soils in Appalachia: high rock fragment content that often causes difficult planting, reduced nutrient availability, and low water-holding capacity. Cuttings of three shrub willow clones were planted with six planting/fertilizer treatments. The planting treatments compared a horizontal planting method that was more efficient than digging full depth holes into compacted and rocky mine soils to traditional vertical planting of cuttings. Fertilizer treatments compared no fertilization to controlled release and traditional fertilizer applied at $140 \mathrm{~kg} \mathrm{~N} \mathrm{ha}^{-1}$. Following the first growing season, clones clearly differed in survival and production but the influence of fertilizer treatments was inconsistent. Horizontal planting impeded cutting survival in rocky planting conditions. Survival and growth were lower for horizontally-planted cuttings relative to vertically-planted cuttings. Response to fertilizer varied by clone. Results of this study will be used to direct future establishment practices for willow on reclaimed mine soils in West Virginia.
\end{abstract}

Additional Key Words: reclamation, revegetation, short rotation coppice, planting methods

${ }^{1}$ Oral paper presented at the 2016 National Meeting of the American Society of Mining and Reclamation, Spokane, WA: Reclaiming the West, June 4 - 9, 2016. Published by ASMR; 1305 Weathervane Dr., Champaign, IL 61821.

${ }^{2}$ Bart Caterino, MS Candidate; Jamie Schuler, Professor; and Shawn Grushecky, Professor, respectively, Forestry and Natural Resources, West Virginia University, Morgantown, WV 26506; and Jeff Skousen, Professor, Plant and Soil Sciences, West Virginia University, Morgantown, WV 26506

DOI: http://doi.org/10.21000/JASMR17010001 


\section{$\underline{\text { Introduction }}$}

West Virginia's coal fields contained over 22,500 hectares of surface mined land available for biomass plantation development (Maxwell et al., 2012). Those lands were categorized as barren land and mines reclaimed to grass land with slopes less than 10\%. State legislation in 2000 shifted the preferred post-mining land use from pasture to reforestation with native hardwoods for timber production and wildlife habitat (Gorman et al., 2001). Experimental cultivation of woody crops for biomass energy has offered mine operators an alternative to achieve bond release. Biomass plantations have the possibility to produce a crop within five years in comparison to the multidecade rotations of timber production. Mine operators gain the opportunity to produce a salable product for the energy industry, and in turn, the energy industry stands to gain a supply of biomass feedstock that may be used in co-firing applications with existing coal fuels.

Willow (Salix spp.) biomass co-firing has been successfully implemented in coal-burning power plants both in the United States (e.g., Dunkirk, NY) and internationally (e.g., Enköping, Sweden). Trials have concluded that willow firing can help power plants reduce sulfur $\left(\mathrm{SO}_{2}\right)$ and nitrogen emissions $\left(\mathrm{NO}_{\mathrm{x}}\right)$ as regulations tighten (Sami et al., 2001). Keoleian and Volk (2005) found that $\mathrm{NO}_{\mathrm{x}}$ and $\mathrm{SO}_{2}$ emissions were reduced by $5.2 \%$ and $9.5 \%$, respectively, during $10 \%$ willow co-firing. Additionally, they have documented a neutral carbon balance for willow cultivation and firing. Biomass offers the energy industry an alternative fuel that will aid in emissions reduction.

Willow plantations on agricultural sites have yielded more than 20-30 dry tonnes (DT) ha $\mathrm{hr}^{-1} \mathrm{yr}^{1}$ (Volk et al., 2016). Agricultural soils represent an ideal situation for willow cultivation. Soil textures in most agricultural settings are sandy loams and silt-loams, are readily tilled to reduce bulk density, and are easily planted with willow cuttings. While cultivating biomass exclusively on agricultural sites would provide adequate yields for bioenergy conversion, the conversion of large areas of agricultural land from food production to biomass production conjures social and pragmatic challenges from a food-production standpoint (Campbell et al., 2008), sometimes called the food to fuel debate. In response, the energy industry has looked to abandoned croplands and marginal lands, including mine reclamation sites for available land.

Mine soils are commonly coarse-textured with high rock fragment content and high (1.7$1.8 \mathrm{Mg} \mathrm{m}^{-3}$ ) bulk density due to compaction to prevent erosion (DeLong et al., 2012). Compaction 
and high rock fragment content cause difficult conditions for manual planting of willow cuttings and hinder root establishment. Further documented problems with mine soils include $\mathrm{pH}$ extremes (below 4.0 and above 8.0), poor fertility, and poor water holding capacity (Gorman et al., 2002; Seybold et al., 2004). Willow grows best in loamy soils with a rooting zone of $45 \mathrm{~cm}$ or greater with $\mathrm{pH}$ between 5.5 and 7.0 (Abrahamson et al., 2010).

The past decade has seen mine soil conditions improved on reclaimed mine sites due to operators following the recommendations provided by researchers with the Appalachian Regional Reforestation Initiative (ARRI) (Burger et al., 2005). The recommendations in ARRI's "Forest Reclamation Advisories" emphasized improved topsoil substitutes and loose grading for reduced bulk density. Techniques for improved soil fertility, organic matter incorporation, and increased water holding capacity are the subjects of continuing mine soil research. Concurrent research on mine soils with willow varieties, their growth habits, and site tolerances will serve to create willow systems that produce sustained yields, adequate for bio-energy applications.

The keys to achieving high productivity on mine soils may be found by identifying appropriate willow species/clones based on growth habit, site tolerances, and response to silvicultural treatments (Stolarski et al., 2014). At present, over 125 clones exist of the subgenus Caprisalix (Vetrix) which is used in biomass plantations (Keoleian and Volk, 2005; Volk et al., 2006). Each clone varies in growth habit, climate adaptation, and site tolerance. Site suitability studies by Volk et al. (2006) have concluded that genetic diversity makes willow biomass cultivation possible on sites with varied climate and soil conditions. Riparian varieties, in particular, have demonstrated superior ability to establish large root systems even on impoverished sites (Mosseler et al., 2014).

It was expected that mine soils would provide a true test of each clone's adaptability to impoverished soils and droughty conditions. A horizontal planting method aimed to capitalize on willow's vigorous ability to propagate roots and shoots (Mosseler et al., 2014). Larsen et al. (2014) conducted trials of horizontal planting of $0.2 \mathrm{~m}$ willow cuttings that produced comparable yields to vertically-planted cuttings. This treatment was expected to test the rooting ability of each clone and to test a planting method that may be more efficient than digging full depth holes into compacted and rocky mine soils. 
Fertilizer treatments were expected to ease some of the nutrient deficiency and aid survival and growth of willow in mine soils. The benefits of nitrogen fertilizer application have been demonstrated by Adegbidi et al. (2003) which showed that willow yield increased by $25 \%$ with fertilization at $100 \mathrm{~kg} \mathrm{~N} \mathrm{ha}^{-1}$ over the control group on agricultural soils. Casselman et al. (2006) found positive response of hybrid poplar volume production to weed control, tillage, and fertilization on mine soils in Ohio, Virginia, and West Virginia. The objective of this study was to compare how planting method and fertilizer treatment affected the first-year growth of three willow clones. It was expected that the success of the horizontal-planting treatment would be influenced heavily by moisture stress. Efficacy would be evident from the survival rates in comparison to traditional planting. Fertilizer response, as measured by first-year volume growth, was expected to differ between fertilizer type and among clones. The results of this first-year study will be used to direct willow planting on similarly prepared sites for the upcoming growing season.

\section{Materials and Methods}

The C-1 surface mine is located near Mount Storm, Grant County, WV (39.133639,79.281323). The site was mined for the Elk Lick, Bakerstown, and Mahoning coal seams. Overburden material is a mixture of shales and sandstones from the Conemaugh Group from the Pennsylvanian Period. Topsoil was salvaged and re-spread loosely over the graded overburden in July 2014. Soils were amended and hydro-seeded in September 2014 as shown in Tables 1 and 2. Table 1. Reclamation soil amendments applied to minesoils at the $\mathrm{C}-1$ mine.

\begin{tabular}{|c|c|}
\hline Soil Amendment & Rate \\
\hline & -------------- kg ha' ${ }^{-1}$-------------- \\
\hline Lime & 5,000 \\
\hline Mulch & 2,200 \\
\hline Nitrogen & 100 \\
\hline Phosphorus & 220 \\
\hline Potassium & 220 \\
\hline
\end{tabular}

Table 2. Reclamation seed mix applied to minesoils at the C-1 mine.

\begin{tabular}{|c|c|}
\hline Seed & Rate \\
\hline & --------------- kg ha' ${ }^{-1}$--------------- \\
\hline Birdsfoot Trefoil & 17 \\
\hline Orchard Grass & 17 \\
\hline Red Top & 6 \\
\hline Oats/Perennial Rye/Japanese Millet & 50 \\
\hline
\end{tabular}


Mine soils were coarse textured. Composition was determined from six soil samples taken from 0 to $30 \mathrm{~cm}$ depth across the experimental plots. Soil composition was approximately $60 \%$ gravel, 30\% sand and 10\% silt and clay by mass (ASTM International, 2009). Soil bulk density was measured at $1.5 \mathrm{Mg} \mathrm{m}^{-3}$ by the excavation-water method (Page-Dumroese et al., 1999).

Results from twelve soil samples taken from 0 to $30 \mathrm{~cm}$ depth across the experimental plots, and analyzed by the West Virginia University Soil Testing Lab using Melich 1 extraction, indicated an average soil $\mathrm{pH}$ of 4.6. Potassium levels as $\mathrm{K}_{2} \mathrm{O}$ were $110 \mathrm{~kg} \mathrm{ha}^{-1}$ on average. Phosphorus levels as $\mathrm{P}_{2} \mathrm{O}_{5}$ averaged $33 \mathrm{~kg} \mathrm{ha}^{-1}$. Average cation exchange capacity of the minesoil was 12.5 meq $100 \mathrm{~g}^{-1}$.

Weather data for the 2015 growing season was acquired from the National Weather Service station at Bayard, WV approximately $24 \mathrm{~km}$ to the northwest of the C-1 mine (AgACIS, 2016). Average temperature for the April through September period was $15.8{ }^{\circ} \mathrm{C}, 0.6{ }^{\circ} \mathrm{C}$ greater than normal. Precipitation throughout the period was $2.6 \mathrm{~cm}$ greater than normal, with notable belownormal periods in May (7.1 cm below normal) and July $(3.0 \mathrm{~cm}$ below normal).

Willow clones selected for this study were SX61 (Salix sachalinensis), Fish Creek (S. purpurea), and Preble (S. viminalis $x$ S. miyabeana). The clones are promoted by The State University of New York College of Environmental Science and Forestry (SUNY-ESF) and Cornell University as fast growing and high yielding, suitable for bio-energy applications.

According to the respective fact sheets, all clones are "adaptable to a wide range of soil and moisture conditions" and "[prefer or require] maximum sunlight" (Cameron et al., 2007a; Cameron et al., 2007b; Gouker et al., 2015). SX61 is a variety native to Asia. Fish creek is a cross between two $S$. pupurea cultivars that reportedly produced $30 \%$ greater biomass than its parents. Preble was shown to produce $18 \%$ greater biomass than SX61, the highest yielding cultivar.

Twelve whole plots each consisted of 60 willow cuttings planted in double row arrangement at a spacing of $0.76 \mathrm{~m}$ between paired rows and $0.61 \mathrm{~m}$ down rows (Fig. 1). Spacing between double rows was $3.6 \mathrm{~m}$. Cuttings were planted during the third week of April 2015. The three fertilization treatments, no fertilizer, coated fertilizer and standard fertilizer, were administered at the whole-plot level and replicated four times. Fertilizer was administered at the beginning of the first growing season during the third week in May 2015. Fertilizer was obtained from the Southern 


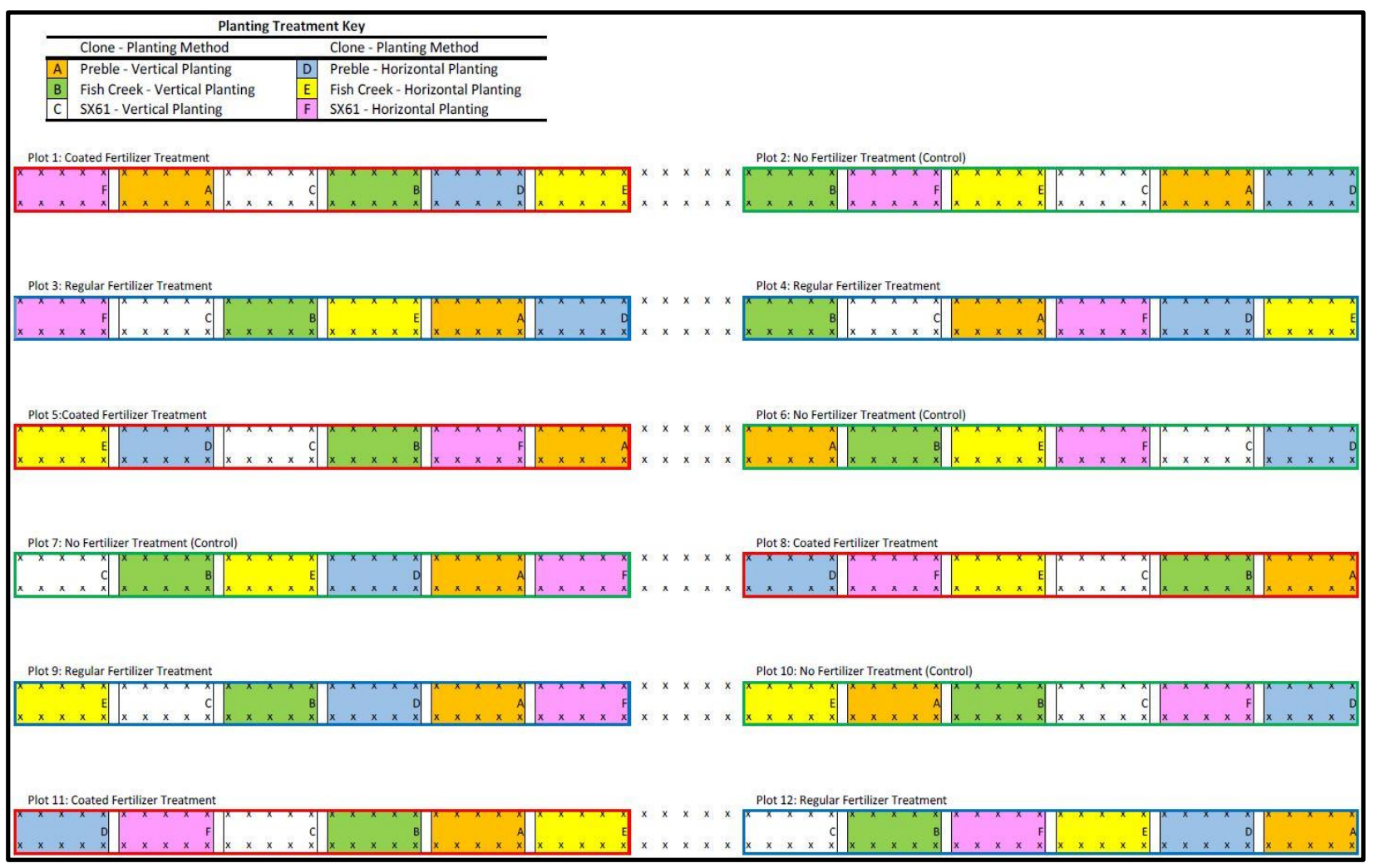

Figure 1. Willow planting layout showing four experimental replicates. Crosses indicate individual willow plants. Main plot fertilizer treatments are assigned randomly and identified. Sub-plot labels/colors indicate the randomly assigned clone and planting method.

States Cooperative (Morgantown, WV). Equal applications of "The Andersons" standard 10-1010 fertilizer or "Earth-Gro" 10-10-10 time-release fertilizer was administered at a rate of $140 \mathrm{~kg} \mathrm{~N} \mathrm{ha}^{-1}$ (Kopp et al., 1996). The 10-10-10 supplied $0.7 \mathrm{~kg} \mathrm{~N}, 0.3 \mathrm{~kg} \mathrm{P}$, and $0.5 \mathrm{~kg} \mathrm{~K}$ per plot. Within each whole plot, six sub-plots were randomly assigned to three clones and two planting methods in factorial arrangement (Fig. 1). Vertically-planted cuttings were inserted into the soil with $2.5 \mathrm{~cm}$ or less of the cutting above the soil surface (McCracken et al., 2010). Horizontally planted cuttings were placed slightly below the soil surface and covered over with soil. Each sub-plot consisted of ten willow cuttings.

At the recommendation of Albertsson et al. (2014), willow establishment required control of competing vegetation in the vicinity of plantings. Competition from broadleaves was controlled with pre-emergent herbicide application of oxyflourfen (Goal 2XL; Dow Agrosciences) at a rate of 4.7 $\mathrm{L} \mathrm{ha}^{-1}$. Grasses were controlled with pre-emergent application of glyphosate (Roundup; Monsanto Company) at a rate of $7 \mathrm{~L} \mathrm{ha}^{-1}$. Post-emergent competition was controlled with 
sethoxydim (Poast; BASF Company) at a rate of $1.5 \mathrm{~L} \mathrm{ha}^{-1}$. Water was the carrier for all herbicides. No surfactants were used.

First year growth and survival measurements were performed on September 24, 2015. Survival was determined by the presence of live leaves and/or live buds. Survival percentages were calculated per sub-plot. Growth measurements took basal stem diameters and heights of each shoot for each living individual. A volume was calculated for each living individual by summing the basal area of each branch and applying equation 1, below:

$$
V=\Sigma\left(D^{2} H\right)
$$

where $\mathrm{D}=$ basal branch diameter $(\mathrm{cm})$ and $\mathrm{H}=$ shoot height $(\mathrm{cm})$.

Volumes of living individuals were averaged by sub-plot for analysis. Survival and volume data were analyzed with SAS 9.4 (SAS Institute, Cary, NC) with a three-factor ANOVA using the Glimmix procedure to assess significant differences among fertilizer, clone, and planting position factors (Kiernan et al., 2011). The model included random effects of the four experimental replications on the fertilizer (whole plot) factor (Kaps and Lamberson, 2004). Least squares means comparisons were used to compare individual treatments within significant main effects. Simple effect comparisons by slices, with Holm-Tukey correction for multiple comparisons, was utilized to compare the effects of individual treatment combinations within significant interactions (Kiernan et al., 2011).

\section{$\underline{\text { Results }}$}

Survival of willow primarily differentiated based on planting method ( $\mathrm{p}<0.0001)$ and clone $(\mathrm{p}=0$.0063). Survival of vertically-planted cuttings was 93\%, 32\% more frequent than horizontally-planted cuttings (Table 3). Compared among clones, survival of Preble (89\%) exceeded both SX61 and Fish Creek by approximately 15\% (Table 4).

Table 3. Willow survival summarized by planting method. Numbers in parentheses indicate standard errors.

\begin{tabular}{lc}
\hline Planting Method & Survival \\
\hline & $-----\%$-------- \\
Horizontal & $65(4.1) \mathrm{b}^{\dagger}$ \\
Vertical & $93(3.0) \mathrm{a}$ \\
\hline
\end{tabular}

\footnotetext{
†Values followed by the same letter not significantly different at $p=0.05$ level.
} 
Table 4. Willow survival summarized by clone. Numbers in parentheses indicate standard errors.

\begin{tabular}{lc}
\hline Clone & Survival \\
\hline & $73(6.1) \mathrm{b}^{\dagger}$ \\
Fish Creek & $89(3.6) \mathrm{a}$ \\
Preble & $75(5.1) \mathrm{b}$ \\
\hline
\end{tabular}

Values followed by the same letter not significantly different at $p=0.05$ level.

Analyses indicated an interaction of the effects of planting and clone on survival $(\mathrm{p}=0.0400)$ (Fig. 2). Horizontal planting did not negatively affect survival of the Preble clone while it caused substantial losses of both SX61 ( $<$.0001) and Fish Creek cuttings ( $\mathrm{p}=0.0013)$. Among clones, vertically-planted stems survived at similar rates ranging from 86 to $95 \%$.

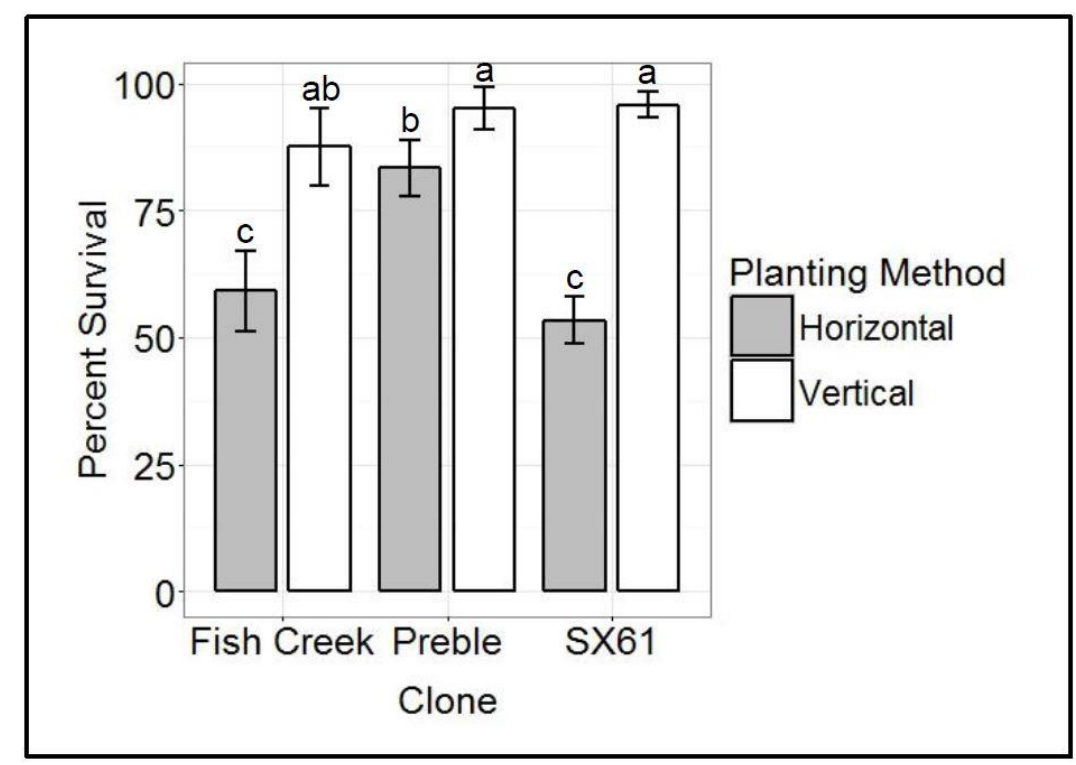

Figure 2. Survival of willow summarized by the interaction of planting method and clone treatments. Error bars denote standard error around the mean. Results displaying different letters denote statistical difference at $p=0.05$ level.

In the first year, clone had the only main effect on differences in growth as measured by volume $(\mathrm{p}<0.0001)$. Pairwise tests indicated that Preble was the greatest volume producer with $10 \mathrm{~cm}^{3}$ over Fish Creek $(\mathrm{p}=0.0258)$ and $4 \mathrm{~cm}^{3}$ over SX61 $(\mathrm{p}=0.0433)$ (Fig. 3). The interaction of fertilizer and clone treatments $(\mathrm{p}=0.0112)$ indicated increases in volume growth for the Preble and SX61 clones while Fish Creek growth did not respond to fertilizers (Fig. 4). For the Preble 
clone, regular fertilizer provided the only significant volume increase $(\mathrm{p}=0.0145)$. For SX61 only coated fertilizer caused significant volume increase over the control treatment $(p=0.0116)$.

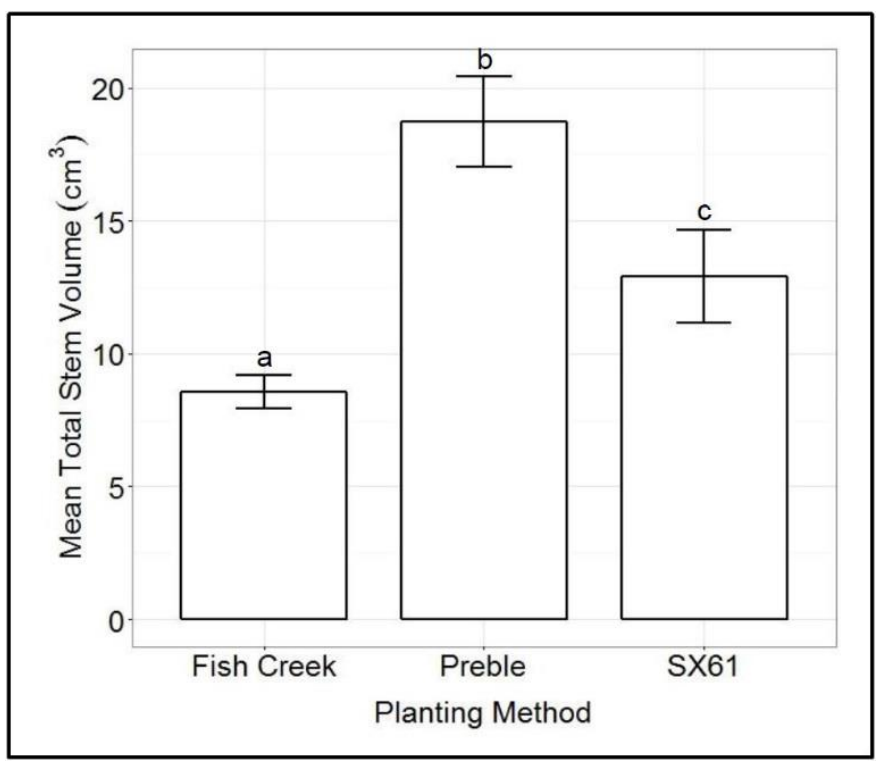

Figure 3. Overall mean total stem volume production by each willow clone. Error bars denote standard error around the mean. Result displaying different letters denote statistical difference at $p=0.05$ level.

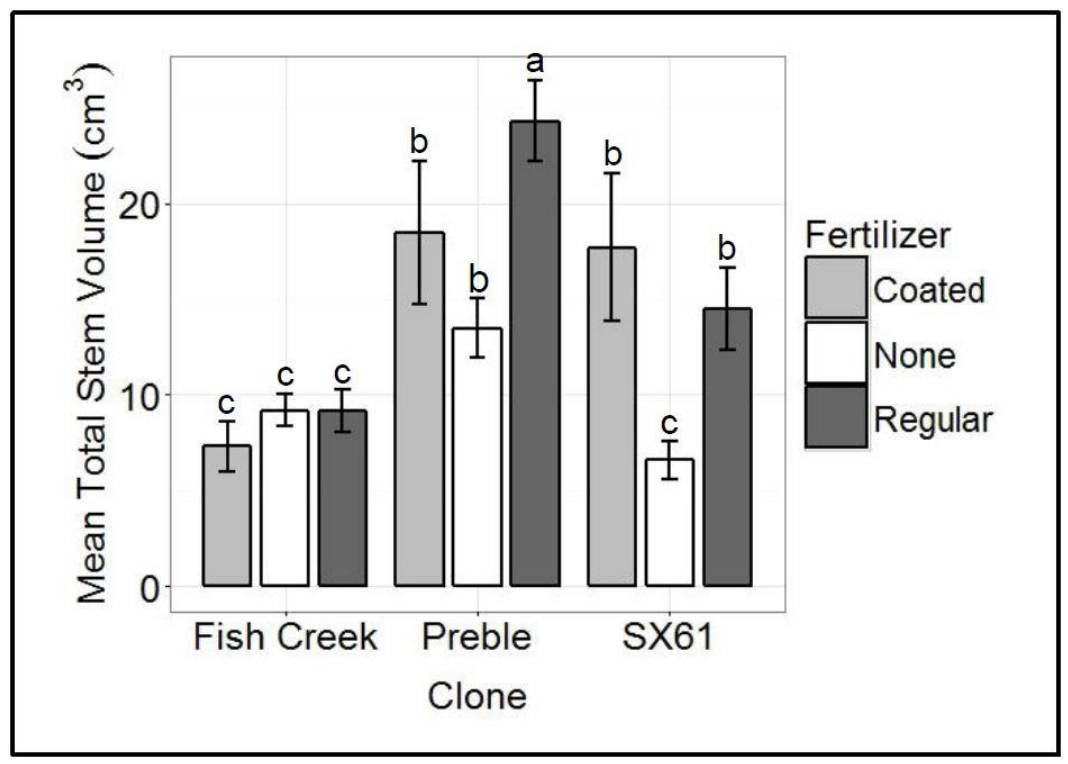

Figure 4. Mean total stem volume of willow compared according to the interaction of clone and fertilizer treatments. Error bars denote standard error around the mean. Result displaying different letters denote statistical difference at $p=0.05$ level. 


\section{$\underline{\text { Discussion }}$}

After the first growing season, it was apparent that the horizontal planting treatment was not a viable method to contend with rocky planting conditions. Although some horizontal-planted cuttings did root and shoot, they were subject to drier conditions at the soil surface which resulted in poor growth. The period of below-normal rainfall in May, shortly after planting, was detrimental to initial rooting. A significant number of cuttings died before developing sufficient root systems for survival. Horizontal cuttings that established roots were likely too shallow to access soil moisture at lower depths during dry periods in May and July. McCracken et al. (2010) reported similar moisture limitations in their trials of horizontally-planted willow at $8 \mathrm{~cm}$ depth versus the $20 \mathrm{~cm}$ reach of vertically-planted cuttings. There may be a minimum depth for successful horizontal planting, which the planting method at the $\mathrm{C}-1$ site did not reach. Digging deeper than the surface for horizontal planting would defeat the labor reduction motivation for our study on mine soils.

The genotypic strength in the Preble willow clone was evident in the establishment year. Preble's survival rate was above those of SX61 and of Fish Creek and was the most stable between planting treatments. This indicated an ability to survive under water stress that other clones did not exhibit. That Preble produced the greatest volume, was consistent with its proving trials on agricultural soils in central New York State where it out-yielded SX61 by 18\% (Gouker et al., 2015). The poor growth of Fish Creek, relative to SX61 may have been caused by sensitivity to soil acidity. Serapiglia et al. (2013) found that Fish Creek yield was less on soil with a pH of 5.0 compared to a soil with pH of 6.5 , whereas SX61 produced consistent yields across soils. Fertilizer additions may have intensified soil acidity, hence the negative response of Fish Creek to fertilization. Preble and SX61 exhibited a greater affinity for utilizing the supplied nutrients. Their largest volume productions were from fertilized treatments. The differences in response between

fertilizer types for SX61 and Preble may indicate a preference for prolonged small fertilizer inputs versus an initial large fertilizer pulse, respectively. Firmer evidence of the trends seen in the willow plantation is expected after the second growing season.

\section{Conclusions}

Shrub willow survived the first growing season on a coarse, rocky mine soil in West Virginia. Based on the rate of mortality, horizontal planting was not successful in overcoming rocky planting 
conditions. Survival rates among clones were indicative of a clone's site tolerance which was interpreted as the paramount factor influencing first-year growth. The Preble clone showed advantages over Fish Creek and SX61. Fertilizer treatments showed effectiveness for increasing growth of the Preble and SX61 clones. Further differentiation in aboveground growth among clones and fertilizer treatments is expected following the 2016 growing season.

\section{$\underline{\text { Acknowledgements }}$}

The Appalachian Hardwood Center at West Virginia University

Vindex Energy Corporation - Arch Coal Inc.

West Virginia Division of Energy

\section{$\underline{\text { Literature Cited }}$}

Abrahamson L.P., T.A. Volk, K.E. Kopp, E.H. White, and J.L. Ballard. 2010. Willow biomass producer's handbook (revised). Short Rotation Woody Crops Program, SUNY-ESF, Syracuse, NY.

Adegbidi H.G., R.D. Briggs, T.A. Volk, E.H. White, and L.P Abrahamson. 2003. Effect of organic amendments and slow-release nitrogen fertilizer on willow biomass production and soil chemical characteristics. Biomass \& Bioenergy 25(4):389. https://doi.org/10.1016/S0961$\underline{9534(03) 00038-2}$

AgACIS. Applied Climate Information System [Internet]. 2016. Regional Climate Centers; [cited 2017 Mar 16]. Available from http://agacis.rcc-acis.org/

Albertsson J., D. Hansson, N. Bertholdsson, and I. Åhman. 2014. Site-related set-back by weeds on the establishment of 12 biomass willow clones. Weed Research 54(4):398-407. https://doi.org/10.1111/wre.12086

ASTM International. 2009. ASTM D6913-04(2009)e1 Standard Test Methods for Particle-Size Distribution (Gradation) of Soils Using Sieve Analysis [Internet]. West Conshohocken (PA): ASTM International; [cited 2017 Mar 22] Available from https://doi.org/10.1520/D6913-04R09E01

Burger J.A., D. Graves, P. Angel, V. Davis, and C. Zipper. 2005. Forest Reclamation Advisory No. 2 - The forestry reclamation approach [Internet]. Pittsburgh (PA): U.S. Office of 
Surface Mining, Appalachian Regional Reforestation Initiative; [cited 2016 Nov 22].

Available from http://arri.osmre.gov/Publications/Publications.shtm\#FRAs

Cameron K., L. Smart, T. Volk, and L. Abrahamson. 2007a. Salix purpurea 'Fish Creek' Fact sheet. The Research Foundation of State University of New York.

Cameron K., L. Smart, T. Volk, and L. Abrahamson. 2007b. Salix sachalinensis 'SX61' Fact sheet. The Research Foundation of State University of New York.

Campbell J.E., D.B. Lobell, R.C. Genova, and C.B. Field. 2008. The global potential of bioenergy on abandoned agriculture lands. Environmental Science and Technology 42(15):5791-4. https://doi.org/10.1021/es800052w

Casselman C.N., T.R. Fox, J.A. Burge, A.T., Jones, and J.M. Galbraith. 2006. Effects of silvicultural treatments on survival and growth of trees planted on reclaimed mine lands in the Appalachians. Forest Ecology \& Management 223(1-3):403-14. https://doi.org/10.1016/j.foreco.2005.12.020

DeLong C., J. Skousen, and E. Pena-Yewtukhiw. 2012. Bulk density of rocky mine soils in forestry reclamation. Soil Science Society of America Journal 76(5):1810-5. https://doi.org/10.2136/sssaj2011.0380n

Gorman J., J. Skousen, and J. King. 2002. Initial survival of commercial hardwoods on reclaimed minesoils in West Virginia. In: Barnhisel RI, editor. American Society of mining and Reclamation. ASMR 2002 - Nineteenth Annual Meeting; 2002 June 9-13; Lexington, KY. Lexington (KY): American Society of Mining and Reclamation. p 212-225. https://doi.org/10.21000/jasmr02010212

Gorman J., J. Skousen, J. Sencindiver, and P. Ziemkiewicz. 2001. Forest productivity and minesoil development under a white pine plantation versus natural vegetation after 30 years. In: Barnhisel, R.I., editor. American Society of mining and Reclamation. ASMR 2001 Eighteenth Annual Meeting; 2001 June 3-7; Albuquerque, NM. Lexington (KY): American Society of Mining and Reclamation. p 103-111. https://doi.org/10.21000/jasmr01010103

Gouker F., E. Fabio, and L. Smart. 2015. 'Preble' Salix viminalis x S. miyabeana Fact Sheet. Willowpedia. Horticulture Section, School of Integrative Plant Science, Cornell University. 
Kaps M., and W.R. Lamberson. 2004. Biostatistics for animal science. 1st ed. Cambridge: CABI Publishing. 445 p. https://doi.org/10.1079/9780851998206.0000

Keoleian G.A. and T.A. Volk. 2005. Renewable energy from willow biomass crops: Life cycle energy, environmental and economic performance. Critical Reviews in Plant Sciences 24(5):385-406. https://doi.org/10.1080/07352680500316334

Kiernan K., R. Tobias, P. Gibbs, and J. Tao. 2011 CONTRAST and ESTIMATE statements made easy: the LSMESTIMATE statement. In: SAS Global Forum 2011; 2011 April 4-7; Las Vegas, NV. Cary (NC): SAS Institute Inc. 19 p.

Kopp R.F., L.P. Abrahamson, E.H. White, C.A. Nowak, L. Zsuffa, and K.F. Burns. 1996. Woodgrass spacing and fertilization effects on wood biomass production by a willow clone. Biomass \& Bioenergy 11(6):451-7. https://doi.org/10.1016/S0961-9534(96)00055-4

Larsen S.U., U. Jørgensen, J.B. Kjeldsen, and P.E. Lærke. 2014. Long-term yield effects of establishment method and weed control in willow for short rotation coppice (SRC). Biomass \& Bioenergy 71:266-74. https://doi.org/10.1016/j.biombioe.2014.10.001

McCracken A.R., J.P. Moore, L.R.E. Walsh, and M. Lynch. 2010. Effect of planting vertical/horizontal willow (Salix spp.) cuttings on establishment and yield. Biomass \& Bioenergy 34(12):1764-9. https://doi.org/10.1016/j.biombioe.2010.07.008

Maxwell A., S. Grushecky, and M. Strager. 2012. Biomass Development on Surface Mine Sites in West Virginia: Acreage Potential [Internet]. Morgantown (WV): West Virginia University Appalachian Hardwood Center; [cited 2017 Mar 16]. Available from http://ahc.wvu.edu/component/remository/OTHER/Research/Biomass$\underline{\text { Research/orderby,4/page, } 1 / \text { ?temid }=0}$

Mosseler A., J.E. Major, and M. Labrecque. 2014. Growth and survival of seven native willow species on highly disturbed coal mine sites in eastern Canada. Canadian Journal of Forest Research 44(4):340-9. https://doi.org/10.1139/cjfr-2013-0447

Page-Dumroese D.S., R.E. Brown, M.F. Jurgensen, and G.D. Mroz. 1999. Comparison of Methods for Determining Bulk Densities of Rocky Forest Soils. Soil Science Society of America Journal 63:379-383. https://doi.org/10.2136/sssaj1999.03615995006300020016x 
Sami M., K. Annamalai, M. Wooldridge. 2001. Co-firing of coal and biomass fuel blends. Progress in Energy and Combustion Science 27(2):171-214. ttps://doi.org/10.1016/S0360$\underline{1285(00) 00020-4}$

Serapiglia M.J., K.D. Cameron, A.J. Stipanovic, L.P. Abrahamson, T.A. Volk, and L.B. Smart. 2013. Yield and woody biomass traits of novel shrub willow hybrids at two contrasting sites. BioEnergy Research 6(2):533-46. https://doi.org/10.1007/s12155-012-9272-5

Seybold C.A., R.B. Grossman, H.R. Sinclair, K.M. McWilliams, G.R. Struben, and S.L. Wade. 2004. Evaluating Soil Quality on Reclaimed Coal Mine Soils in Indiana. Proceedings America Society of Mining and Reclamation, 2004 pp 1644-1663 https://doi.org/10.21000/JASMR0401644

Stolarski M.J., M. Krzyzaniak, S. Szczukowski, J. Tworkowski, and A. Bieniek. 2014. Short rotation woody crops grown on marginal soil for biomass energy. Polish Journal of Environmental Studies 23(5):1727-39.

Volk TA, L.P. Abrahamson, C.A, Nowak, L.B. Smart, P.J. Tharakan, and E.H. White. 2006. The development of short-rotation willow in the northeastern United States for bioenergy and bioproducts, agroforestry and phytoremediation. Biomass \& Bioenergy 30(8-9):715-27. https://doi.org/10.1016/j.biombioe.2006.03.001

Volk T.A., J.P. Heavey, and M.H. Eisenbies. 2016. Advances in shrub-willow crops for bioenergy, renewable products, and environmental benefits. Food and Energy Security 5(2):97-106. https://doi.org/10.1002/fes3.82 